УДК 327 (497.5) НАТО

DOI: $10.26693 /$ ahpsxxi2020.02.048

\title{
ОСОБЛИВОСТІ ВСТУПУ ХОРВАТІї ДО НАТО
}

\author{
Олександр Шевчук, \\ e-mail: shevchukovo7@gmail.com \\ ORCID: https://orcid.org/oooo-ooo3-0335-6873 \\ Чорноморський національний університет імені Петра Могили, \\ Украӥна, 54оо3, м. Миколаїв, вул. 68 Десантників, 10 \\ Анастасія Ворчакова, \\ e-mail: dalless20o8@gmail.com \\ ORCID: https://orcid.org/oooo-ooo2-9783-5623 \\ Чорноморсъкий національний університет імені Петра Могили, \\ Украйна, 54оо3, м. Миколаӥв, вул. 68 Десантників, 10
}

Республіка Хорватія, порівняно молода краӥна Західних Балкан, яка проголосила незалежність від Югославї у 1991 р., $і$ з иьього моменту їі зовнішня політика в основному була спрямована на зміцнення зв'язків з західними та європейсъкими структурами. Це не дивно, що однією з цілей Хорватіӥ в цьому відношенні було приєднання до НАТО, через те, що членство в такій організацї надає гарантї̈ війсъкової та політичної безпеки.

Взятий Хорватією курс євроатлантичної інтеграцї зіштовхнувся із низкою проблем - відсталість економіки, неготовність армї, політичні чвари всередині краӥни та погана поінформованість населення щодо переваг вступу до Альянсу. Однак ефективна зовнішня та внутрішня політика Загребу, а також усвідомлення членами НАТО стратегічного значення вступу Хорватї̈ для забезпечення безпеки на Балканському півострові дозволили хорватам досягти поставленої мети.

У статті розкрито дї Хорватӥ на шляху до членства у НАТО. Висвітлено сутність щорічних національних програм Хорватї̈, які були планами змін та реформ задля вступу до НАТО. Досвід Хорватї є корисним для Украӥни, адже Хорватія - це краӥна, яка змогла провести відповідні реформи та вступити до НАТО після війни та економічних проблем.

Ключові слова: НАТО, Хорватія, програма «Партнерство заради миру», зовнішня політика, євроатлантична інтеграція

Постановка проблеми. Після розпаду Югославії першочерговою метою Хорватії стало повноцінне членство в євроатлантичних структурах. Однак цей шлях значно уповільнився через війну за незалежність та боротьбу із сербською агресією, наслідки якої вимагали більшої кількості реформ від хорватського керівництва, які необхідно було провести задля вступу до НАТО. Взятий Хорватією курс євроатлантичної інтеграції зіштовхнувся із низкою проблем - відсталість економіки, неготовність армії, політичні чвари всередині країни та погана поінформованість населення щодо переваг вступу до Альянсу. Однак ефективна зовнішня та внутрішня політика Загребу, а також усвідомлення членами НАТО стратегічного значення вступу Хорватії для забезпечення безпеки на Балканському півострові, дозволили хорватам досягти поставленої мети.

Шлях кожної держави до членства в НАТО та ЄС є неповторним, оскільки він обумовлений геополітичними, історичними й економічними факторами. У той же час Україна може повчитися послідовності та стійкості хорватів у провадженні необхідних внутрішніх реформ і трансформації задля досягнення членства у НАТО. 
Ступінь наукової розробки проблеми. Особливості вступу Хорватії до НАТО досліджують вітчизняні та закордонні науковці. Зокрема, серед українських вчених варто виокремити роботу I. Боровець ${ }^{1}$ в якій розкрито деякі аспекти євроатлантичного напряму зовнішньої політики Хорватії. Серед закордонних авторів більшість складають хорватські дослідники. Зокрема, слід виділити праці Д. Джовіча 2 , С. Ленкіча 3 , В. Павлаковіча 4 , М. Зубовича 5 , в яких йдеться про розвиток євроатлантичного вектора хорватської зовнішньої політики, перш за все про історичний шлях держави до НАТО та переваги членства в Альянсі. Республіка Хорватія у своїй історії пережила досить складний період, пов'язаний з війною 1991-1995 рр., після оголошення про вихід із СФРЮ.

Методи та прийоми дослідження. Дослідження грунтується на використанні комплексу загальнонаукових і спеціальних методів пізнання. Методи системного та структурного аналізу були використані при систематизації наукової інформації за темою роботи. Застосування системного підходу забезпечило теоретичне узагальнення наукових поглядів вітчизняних і зарубіжних вчених, присвячених дослідженню євроатлантичного вектору зовнішньої політики Хорватії. Крім того, у даному дослідженні були застосовані загальнонаукові методи аналізу та синтезу, індукції та дедукції. Використання історичного методу дало можливість дослідити процес становлення та розвитку євроатлантичного вектору зовнішньої політики Хорватії. Головним методом дослідження є проблемно-хронологічний, який дозволяє розглянути проблеми в їх часовій послідовності та динаміці.

Викладення основного матеріалу. 3 офіційних документів на веб-сайті НАТО видно, що погляд НАТО на Хорватію змінився після 2000 р., коли вона почала набагато частіше згадуватися в офіційних документах. Хоча Хорватія й заявила 25 червня 1991 р. про незалежність, яку НАТО відзначив у своїх новинах, в офіційних текстах НАТО про Хорватію почали згадувати лише у 1993 р.

Перша згадка про Хорватію в офіційних документах НАТО зафіксована 21 серпня 1991 р. у Заяві НАТО «Про ситуацію в Радянському Союзі», в якій лише сказано про «кризу в Югославії» та підтримку НАТО, НБСЕ та Європейському співтовариству у вирішенні кризи. Оскільки ситуація не заспокоїлась, у листопаді 1991 р. на Римському саміті НАТО було видано спеціальну заяву під назвою «Ситуація в Югославії», де НАТО заявило про свою стурбованість руйнуваннями та кількістю жертв 6 .

НАТО також назвали головного винуватця у війні в Хорватії - «Постійні напади JNA на Дубровник та інші міста країни, які були несумірні з будь-якими провокаціями, будь-якими порушеннями припинення вогню або необхідністю захисту сербських громад або військових гарнізонів». НАТО згадує «хорватські міста» 3 особливим акцентом на Дубровник.

Після визнання Хорватії 15 січня 1992 р. в документах НАТО вже не згадується Югославія, а «колишня Югославія». Після засідання від 10 липня 1992 р. НАТО перестало бути пасивним спостерігачем і стали активним учасником миротворчих операцій. А саме, військово-морські сили під егідою НАТО приєдналися до конт-

\footnotetext{
${ }^{1}$ Боровець, I. (2015). Особливості процесу інтеграції Республіки Хорватія до Європейського Союзу. Міжнародні зв'язки Украӥни: наукові пошуки і знахідки, 24, 303-318.

2 Jović, D. (2011). Hrvatska vanjska politika pred izazovima clanstva u Europskoj Uniji. Poloticka misao, 48, 2, 7-36.

3 Lenkić, S. (2016). Percepcija uloge Hrvatske u NATO savezu i suvremenim geopolitičkim odnosima u svijetu. Zadar. Retrieved from https://repozitorij.unizd.hr/islandora/object/unizd:199 4 Pavlaković, V. (2010). Croatia, the International Criminal Tribunal for the former Yugoslavia, and General Gotovina as a Political Symbol. Europe-Asia Studies, 62, 10, 1707-1740.

5 Zubovic, M. (2019). Republic of Croatia's Membership in NATO. Проблемы постсоветского пространства, 6 (4), 390-397.

${ }^{6}$ Lenkić, Š. (2016), 50.
} 
ролю над Адріатикою, щоб контролювати дотримання ембарго ООН, тобто ембарго на озброєння колишньої Югославії та економічне ембарго на СРЮ7.

Варто зауважити, що під час війни у Хорватії, риторика НАТО була більше пробоснійською, ніж прохорватською. Однак, після підписання Дейтонської угоди розпочався новий період як для Боснії та Герцеговини, так і для Хорватії. На конференції в Мюнхені генеральний секретар НАТО вперше заговорив про наміри Хорватії, Боснії та Герцеговини й Югославії стати частиною Північноатлантичної громади.

Саме на початку 1996 р. стратегічними напрямами зовнішньої політики Республіки Хорватії стають вступ до ЄС і НАТО. Генеральний секретар НАТО у Мюнхені зазначив, що успішний вступ у НАТО повністю залежить від їх дотримання Дейтонських угод 8 .

У 1996 р. хорватський уряд офіційно подав заявку на програму «Партнерство заради миру», але на той час Хорватія ще не виконала всіх необхідних умов і їй ще треба вирішити деякі післявоєнні питання. Тому до Програми її не взяли.

У 1998 р. після успішної, мирної реінтеграції східної частини Хорватії, умови для активізації переговорного процесу з євроатлантичними структурами було виконано9. У 2000 р. Республіка Хорватія повторно подала заявку до програми «Партнерство заради миру». НАТО у відповідь наголосило на необхідності інтенсифікації зовнішньої політики країни та вирішення питання повернення сербських біженців, а також налагодження тіснішого співробітництва з Міжнародним Кримінальним трибуналом для колишньої Югославії.

Позитивні політичні процеси, що відбулося у Хорватії, продемонстрували готовність країни до трансформації своєї зовнішньої політики, що прискорило рішення НАТО запросити Хорватію до програми «Партнерство заради миру»10.

25 травня 2000 р. Хорватія стала членом програми «Партнерство заради миру» та Ради євроатлантичного партнерства. Це був перший великий крок на шляху країни до НАТО.

Після приєднання до програми «Партнерство заради миру», хорватський уряд почав шукати шляхи для приєднання країни до Плану дій щодо членства. Хорватія передала свою першу Щорічну національну програму (2002/2003), в якій вона підтвердила свою прихильність до системи цінностей НАТО і ще раз наголосила на прагненнях набути статусу члена Альянсу.

До 2002 р. Хорватія брала активну участь у низці заходів і програм у складі програми «Партнерство заради миру» (семінари, військові навчання, конференції тощо) та співпрацювала у сфері планування надзвичайних ситуацій у цивільних ситуаціях ${ }^{11}$. Перша хорватська Щорічна національна програма зіткнулася 3 деякою критикою з боку НАТО, здебільшого щодо прикордонного питання зі Словенією (Піранська затока), але низку інших реформ було схвалено.

У 2003 р. Хорватія представила свою другу Щорічну національну програму (2003/2004), в якій було зроблено більший акцент на регіональному співробітництві та розвитку відносин з сусідніми країнами. Однак, НАТО знову звернула увагу на питання кордону зі Словенією та наголосила на співробітництві з Міжнародним Кримінальним трибуналом для колишньої Югославії. Мова йшла про вирішення ситуації хорватського генерал-лейтенанта Анте Готовіни, головного підсудного у військових злочинах, якому вдалося втекти з країни. До моменту арешту

\footnotetext{
7 Lenkić, Š. (2016), 52.

8 Ibid, 54.

9 Zubovic, M. (2019), 392.

${ }^{10}$ Ministarstvo vanjskih i europskih poslova Republike Hrvatske. Republika Hrvatska i NATO. Retrieved from http://www.mvep.hr/hr/vanjska-politika/multilateralni-odnosio/multi-orginicijative/nato/hrvatska-i-nato/

${ }^{11}$ Ibidem.
} 
Готовіни у 2005 р., Хорватія зазнала значної критики з боку європейських представників ${ }^{12}$.

Щодо реформування власних збройних сил, то НАТО критикувала хорватський уряд за те, що за період 2003/2004 збройні сили все ще не були організовані та розвинені у достатній мірі для їх участі у спільних військових операціях. Необхідно було підвищити мобільність збройних сил та їх готовність приєднатися до операцій НАТО. У 2003 р. Хорватські збройні сили зробили свій внесок в Інтернаціональні Сили сприяння безпеці (ISAF) в Афганістані ${ }^{13}$.

Третя Щорічна національна програма (2004/2005) підкреслювала, що Республіка Хорватія сприймає вступ до НАТО та ЄС як свій основний пріоритет і найважливіший стратегічний план. Більше того, окрім військових сил, керівництво Хорватії прийняло рішення про включення до складу цивільної поліції, а також дипломатів в операції ISAF в Афганістані. Також Хорватія оголосила про готовність країни зробити свій внесок у будь-яку іншу операцію, яку веде НАТО. Хорватія сприяла покращенню ситуації в регіоні, беручи активну участь у програмі НАТО для Сербії та Чорногорії. Зокрема, Хорватія займалася організацією та проведенням таких заходів, як курси по вивченню мови для військових ООН.

Остання четверта Щорічна національна програма (2005/2006) проголосила, що країна має намір активізувати свою участь у ISAF, утричі збільшивши свій контингент шляхом участі в інших операціях. У питанні реалізації регіональних питань, Хорватія підкреслила її готовність зробити свій внесок у підвищення регіональної безпеки, шляхом посилення прикордонного контролю, щоб успішно боротися з тероризмом, торгівлею людьми та торгівлею наркотиками тощо 14.

У четвертій Щорічній національній програмі Хорватія акцентувала увагу на своїх зусиллях щодо співпраці з Міжнародним Кримінальним трибуналом для колишньої Югославії. Протягом 2001-2004 років між Загребом і НАТО спостерігалося напруження через висунення Міжнародним Кримінальним трибуналом для колишньої Югославії обвинувачень проти відомих хорватських генералів Анте Готовіни, Рахіма Адемі та Яна Бобетко за скоєння ними військових злочинів у 1990-х роках. Це загальмувало початок переговорів про членство Хорватії як у HATO, так і в СC аж до 2005 р. Адже у грудні 2005 р. було піймано на Канарських островах і видано міжнародному правосуддю головного військового злочинця Анте Готовіни ${ }^{15}$.

Однак, співпраця Хорватії з Міжнародним Кримінальним трибуналом для колишньої Югославії була негативно сприйнята хорватським суспільством, які виступали проти обвинувачення хорватських військових у злочинах проти людства ${ }^{16}$. Так, 11 лютого 2001 р. у місті Спліт відбулася одна 3 найбільш масштабних демонстрацій, в якій взяло участь більше 150 тис. осіб, які протестували проти ув'язнення хорватським судом генерала Мірко Норца ${ }^{17}$.

Про вкрай негативне сприйняття хорватським суспільством необхідності взаємодіяти з МКТЮ свідчить той факт, що у вересні 2002 р. 84\% хорватів були проти видачі Гаазі генерала Я. Бабетко, з них 71\% були готові терпіти економічні та по-

12 Zubovic, M. (2019), 392.

${ }^{13}$ North Atlantic Treaty Organization. NATO's relations with Croatia. Retrieved from https://www.nato.int/cps/en/natolive/topics_31803.htm

14 Nacionalni program Republike Hrvatske za pridruživanje Europskoj Uniji - 2005. Godina. Retrieved from http://www.mvep.hr/files/file/2014/o5-NPPEU_2005.pdf

15 Боровець, I. (2015), 309.

${ }^{16}$ Batt, J., Obradović, J. (2009 June). War Crimes, Conditionality and the EU integration in Western Balkans. Challiot Papers, 116. Retrieved from https://www.iss.europa.eu/content/warcrimes-conditionality-and-eu-integration-western-balkans

17 Боровець, I. (2015), 309. 
літичні санкції. У лютому 2005 р. 81,4\% населення Хорватії вважали А. Готовіну героєм, а 54,4\% були проти його арешту ${ }^{18}$.

Партії правого спрямування виступали проти проєвропейської та проєвроатлантичної політики загалом. Лунали аргументи щодо антихорватського заколоту за участі Заходу, метою якого було втягування Хорватії до третьої Югославії через криміналізацію хорватських генералів і «Вітчизняної війни». Під час протестів у Загребі в березні 2005 р. хорватські праві сили скандували, що «Готовіні слід подякувати за те, що він врятував Хорватію від $Є C » 19$.

Ці події стали справжнім викликом для євроінтеграційного вибору та євроатлантичного вектору зовнішньої політки країни. Хорватські уряди I. Рачана, а потім I. Санадера, який переміг на чергових парламентських виборах у 2003 р. і повернув ХДС до влади, опинилися не лише на лінії критики Брюсселя, а й у центрі обурення великої частини хорватського суспільства. Водночас, саме у таких непростих умовах відбувся значний переворот на хорватській політичній сцені. Несподівано повернувшись до керування країною у 2003 р., Хорватська демократична спільнота під новим керівництвом Іво Санадера відійшла від колишнього євроскептичного дискурсу $\Phi$. Туджмана, а також антигаазької риторики та прийняла ідею щодо широкої коаліції з Європейським Союзом.

Такий поворот від консервативного антиєвропейського націоналізму до ліберально-консервативного проєвропейського націоналізму відсунув на задній план хорватських сувереністів, які перестали впливати на визначення державної політики ${ }^{20}$.

3 приходом до влади I. Санадер, який не лише почав співпрацювати з Гаазьким трибуналом та усунув 3 провідних партійних посад ультранаціоналістів, а й створив коаліцію з провідною сербською політичною силою - Самостійною демократичною сербською партією, започаткувавши одночасно співробітництво з опозиційними силами у питаннях, що стосувалися ЄC і НАTO.

У 2006 р. на саміті НАТО у Ризі Альянс висловив готовність запросити країникандидати до наступного саміту в Бухаресті 2008 р. Таким чином, вперше Хорватія отримала чіткі часові рамки щодо членства ${ }^{21}$. Вдосконалення, модернізація та управління військовою системою отримали високу оцінку, однак відносна відсутність суспільної підтримки та підтримки серед військовослужбовців членство у НАTO було висунуто як тривожний фактор. Однак з часом негативна думка хорватської громадськості щодо НАТО покращилася і незабаром після саміту в Бухаресті, вступ до НАТО підтримали близько 60\% населення країни 22.

Звіти президента США Дж. Буша від березня та червня 2008 р. про розширення НАТО стосувалися всіх ключових елементів, що містяться у резолюціях щодо вступу Албанії та Хорватії до НАТО. Звіти Буша вказували на спроможність Хорватії бути членом Альянсу, включаючи політичні, економічні, оборонні, бюджетні, правові питання та питання інформаційної безпеки, які містились у Плані дій щодо членства в НАТО. У березневому звіті Буша зазначено, що Хорватія поважає та пропагує основні принципи, закладені у Договорі НАТО, вона має стабільну, багатопартійну, демократичну політичну систему, яка характеризується регулярними виборами та наявністю вільної преси. Збройні сили Хорватії перебувають під цивільним контролем²3.

18 Pavlaković, V. (2010), 1718.

19 Ibid, 1734.

20 Jović, D. (2011), 13.

${ }^{21}$ Ministarstvo obrane Republike Hrvatske. Kronologija ključnih aktivnosti. Retrieved from https://www.morh.hr/kronologija-kljucnih-aktivnosti/

${ }^{22}$ North Atlantic Treaty Organization. NATO's relations with Croatia. Retrieved from https://www.nato.int/cps/en/natolive/topics_31803.htm

23 Christof, A.J. (2009). GAO Report on NATO Enlargement: Albania and Croatia. The Quarterly Journal, 8, 2, 82. 
1 квітня 2009 р. Хорватія депонувала свій документ про ратифікацію та стала членом НАТО. Країна брала участь вже як дійсний член Альянсу на саміті НАTO у Страсбурзі та Келі, який відбувся 3 і 4 квітня 2009 р. ${ }^{24}$.

Отже, Хорватія пройшла складний шлях щодо вступу до НАТО. Досвід Хорватії є корисним для України, адже Хорватія - це країна, яка змогла реформуватись і вступити до НАТО після війни та економічних проблем у країні. Хорватія поступово та послідовно виконувала всі вимоги НАТО, що й стало запорукою успіху в їі євроатлантичних прагненнях.

\section{REFERENCES}

Borovets, I. (2015). Osoblyvosti protsesu intehratsii Respubliky Khorvatiia do Yevropeiskoho Soiuzu [Features of the process of integration of the Republic of Croatia into the European Union]. Mizhnarodni zviazky Ukrainy: naukovi poshuky $i$ znakhidky, 24, 303-318 [in Ukrainian].

Batt, J., Obradović, J. (2009 June). War Crimes, Conditionality and the EU integration in Western Balkans. Challiot Papers, $116 . \quad$ Retrieved from https://www.iss.europa.eu/content/war-crimes-conditionality-and-eu-integration-westernbalkans [in English].

Christof, A.J. (2009). GAO Report on NATO Enlargement: Albania and Croatia. The Quarterly Journal, 8, 2, 75-90 [in English].

Jović, D. (2011). Hrvatska vanjska politika pred izazovima clanstva u Europskoj Uniji. Poloticka misao, 48, 2, 7-36 [in Croatian].

Lenkić, S. (2016). Percepcija uloge Hrvatske u NATO savezu i suvremenim geopolitičkim $\begin{array}{lllll}\text { odnosima } u & \text { Zuijetu. } & \text { Radar. }\end{array}$ https://repozitorij.unizd.hr/islandora/object/unizd:199 [in Croatian].

Pavlaković, V. (2010). Croatia, the International Criminal Tribunal for the former Yugoslavia, and General Gotovina as a Political Symbol. Europe-Asia Studies, 62, 10, 1707-1740 [in English].

Zubovic, M. (2019). Republic of Croatia's Membership in NATO. Problemy postsovetskogo prostranstva, 6 (4), 390-397 [in English].

Oleksandr Shevchuk, Petro Mohyla Black Sea National University, Mykolaiv, Ukraine ORCID: https://orcid.org/oooo-0oo3-0335-6873

Anastasiia Vorchakova, Petro Mohyla Black Sea National University, Mykolaiv, Ukraine ORCID: https://orcid.org/oooo-0oo2-9783-5623

\section{Features of Croatia's accession to NATO}

The Republic of Croatia, a relatively young country in the Western Balkans, declared independence from Yugoslavia in 1991 and since then its foreign policy has been mainly aimed at strengthening ties with Western and European structures. Not surprisingly, one of Croatia's goals in this regard was to join NATO, as membership in such an organization guarantees military and political security.

Croatia's course of Euro-Atlantic integration has faced a number of challenges: economic backwardness, military unpreparedness, political strife within the country and poor public awareness of the benefits of joining the Alliance. However, Zagreb's effective foreign and domestic policies, as well as NATO members' awareness of the strategic importance of Croatia's accession to security in the Balkans, have allowed Croats to achieve their goal.

${ }^{24}$ Ministarstvo vanjskih i europskih poslova Republike Hrvatske. Republika Hrvatska i NATO. Retrieved from http://www.mvep.hr/hr/vanjska-politika/ multilateralni-odnosio/multi-orginicijative/ nato/hrvatska-i-nato/ 
It was after the signing of the Dayton Accords that a new period of Croatia's EuroAtlantic development began. At a conference in Munich, the NATO Secretary General spoke for the first time about Croatia's intentions to become part of the North Atlantic community. And the positive political developments in Croatia have demonstrated the country's readiness to transform its foreign policy, which hastened NATO's decision to invite Croatia to the Partnership for Peace.

The article reveals Croatia's actions on the path to NATO membership. The essence of Croatia's annual national programs, which were plans for changes and reforms for NATO membership, is highlighted. Croatia's experience is useful for Ukraine, as Croatia is a country that has been able to carry out relevant reforms and join NATO after the war and economic problems.

Keywords: NATO, Croatia, Partnership for Peace, foreign policy, Euro-Atlantic integration 